\title{
A new hybrid sewage treatment system combining a rolled pipe system and membrane bioreactor to improve the biological nitrogen removal efficiency: A pilot study
}

\author{
Quang-Vu Bach ${ }^{\text {a, }}$ Van Tam Le ${ }^{\mathrm{b}}$, Yong Soo Yoon ${ }^{\mathrm{b}}$, Xuan Thanh Bui ${ }^{\mathrm{c}}$, Woojin Chung ${ }^{\mathrm{d}}$, Soon \\ Woong Chang d,**, Huu Hao Ngo e , Wenshan Guo e, Dinh Duc Nguyen d,f,* \\ ${ }^{a}$ Sustainable Management of Natural Resources and Environment Research Group, Faculty of \\ Environment and Labour Safety, Ton Duc Thang University, Ho Chi Minh City, Vietnam \\ ${ }^{b}$ Department of Chemical Engineering, Dankook University, 448-701, Republic of Korea \\ ${ }^{c}$ Faculty of Environment and Natural Resources, University of Technology, Vietnam National University, \\ Vietnam \\ ${ }^{d}$ Department of Environmental Energy \& Engineering, Kyonggi University, 442-760, Republic of Korea \\ ${ }^{e}$ Centre for Technology in Water and Wastewater, School of Civil and Environmental Engineering, \\ University of Technology Sydney (UTS), Australia \\ ${ }^{f}$ Institute of Research and Development, Duy Tan University, Da Nang, Vietnam \\ *Corresponding authors. E-mail addresses: bachquangvu@tdt.edu.vn (Q.-V. Bach), \\ swchang@kyonggi.ac.kr (S.W. Chang),nguyensyduc@gmail.com (D.D. Nguyen).
}

\begin{abstract}
A new hybrid pilot plant configuration based on a modularized rolled pipe system (RPS) combined with a submerged flat sheet membrane bioreactor (MBR) was investigated to enhance the sewage treatment and membrane performance. The system was operated under actual conditions for more than four months, that is, at a constant flow rate of $30 \mathrm{~m}^{3} / \mathrm{d}$ and with two internal recycling ratios. The results indicate that the hybrid system produces an excellent effluent quality and considerably mitigated membrane fouling. The average concentrations of SS, $\mathrm{COD}, \mathrm{TN}, \mathrm{NH}_{4}{ }^{+}-\mathrm{N}, \mathrm{NO}_{3}{ }^{-}-\mathrm{N}$, and $\mathrm{PO}_{4}{ }^{3-}-\mathrm{P}$ remained below $2.81,8.29,8.77,0.15,8.17$, and $1.49 \mathrm{mg} / \mathrm{L}$, respectively. It was estimated that the periodic chemical cleaning of the membrane could be extended to approximately six months. The MBR and RPS can virtually complete nitrification and denitrification, respectively. The highest average denitrification rate of the RPS is $116.95 \mathrm{mg} \mathrm{NO}-\mathrm{N} /(\mathrm{g}$ MLVSS d), with a hydraulic retention time of $1.05 \mathrm{~h}$. Therefore, the RPS-MBR hybrid system has potential to improve the sewage treatability. The emerging RPS technique can obtain high rates of denitrification coupled with a compact design, ease of installation, and small footprint.
\end{abstract}

Keywords: Fiber biofilm carrier media; Denitrification; Membrane bioreactor; Modularized rolled pipe system; Membrane fouling mitigation

\section{Introduction}

Nitrogen pollution in wastewater has become an increasingly important global issue. It is a major challenge for wastewater treatment (WWT) facilities to meet the new stricter regulation standards for effluent discharge (Li et al., 2016; Reboleiro-Rivas et al., 2015). Nitrogen pollution has also attracted the attention of the scientific community in recent years, as demonstrated by the increasing number of publications about related topics. Because the nitrogen accumulation can exceed the threshold of natural absorption by water, excess nitrogen is considered one of the main reasons 
contributing to the eutrophication process, which can seriously disrupt the stability of ecosystem functioning (Gonçalves et al., 2016; Halling-Sørensen and Jorgensen, 1993). It may impact the development of aquaculture and tourism (van Rijn et al., 2006). Excess nitrogen in water can be a risk to human health, especially for infants and pregnant women (Oram, 2011; Urbaniec et al., 2017; Yang and Zhang, 1995).

Nitrogen in wastewater can be transformed into free nitrogen based on two principal biological processes, that is, nitrification in aerobic zones and denitrification in anoxic/anaerobic zones by autotrophs and heterotrophs, respectively (Kalyuzhnyi et al., 2006; Metcalf et al., 2004). To reduce nitrogen concentrations in effluents, various biological wastewater treatment processes incorporating a membrane separation system have been developed and applied. A membrane bioreactor (MBR) represents the incorporation of a membrane separation technique into the aerobic activated sludge process. The MBR is a pioneering and promising technology for wastewater treatment that has been widely applied in the last two decades because it offers numerous advantages over conventional wastewater treatment processes such as a smaller footprint, higher effluent quality, higher biomass concentration, less sludge production, and better disinfection (Judd, 2010; Le-Clech et al., 2006). Despite these advantages, rapid fouling of the membrane can occur during the filtration process, mainly due to the accumulation of particles and growth of biofilms on and/or within the membrane pores. This issue has limited the application of the MBR (Duan et al., 2013; Geng et al., 2007; Hua et al., 2015) and has created the urgent need to find solutions for mitigating membrane fouling.

The primary roles of the MBR are the treatment of organic compounds, transformation of ammonium nitrogen into nitrate, and separation of solids and liquids via membranes (Judd, 2010; Tan and $\mathrm{Ng}, 2008$ ) because the produced nitrates require further treatment and control before discharge into the environment. The presence of nitrate in water is a potential cancer risk (Oram, 2011) and is connected to other related issues outlined above. Based on the provisions of the United States Environmental Protection Agency (EPA) and the recommendations of the World Health Organization (WHO), the nitrate concentration in drinking water should not exceed $10 \mathrm{mg} / \mathrm{L}$ (Yang and Zhang, 1995).

Considerable efforts have been made to reduce the produced nitrate using the MBR technology. The most common method is recycling of the nitrate-rich sludge into separate anoxic zones, which are located in front of the entrance of the MBR such that denitrifying bacteria can utilize the organic carbon compounds of the influent wastewater as carbon and energy sources for denitrification. However, these technologies require large quantities of nitrate recirculation flow into anoxic zones (Judd, 2010; Ng et al., 2006) or various recycling systems (Syron and Casey, 2008) and numerous mechanical devices for complete mixing, resulting in high energy use and requiring an anoxic reactor with a large volume, which can lead to engineering problems and high costs (Delrue et al., 2011; Yoon et al., 2004).

Furthermore, large quantities of the nitrified mixed liquor recycle flow carry a large amount of dissolved oxygen from the oxic zone of the MBR to the anoxic zone, which in turn impacts the denitrification metabolically and kinetically, causing subsequent reduction of the rate and 
efficiency of the denitrification process under anoxic conditions (Ge et al., 2010; Plósz et al., 2003; Tan and Ng, 2008).

In the present study, a large-scale hybrid pilot plant comprising a modularized rolled pipe system (RPS) and MBR is proposed to overcome the aforementioned drawbacks. In addition to taking advantage of the inherent strengths of the MBR, we replaced the conventional anoxic tank with a RPS. The RPS is a recently developed, innovative, and robust technology and contains soft fiber media with highly porous and large surface areas, arranged along the entire length of the pipe to facilitate the attachment, growth, and activity of denitrifying microorganisms. When the wastewater flows through the RPS in axial direction, the greatest amount of contact is ensured between the contaminants in the wastewater flow and microbial community attached to the fiber media.

The RPS has been operated under anoxic conditions to: firstly, enhance the rate and efficiency of the denitrification process; and secondly, reduce extracellular polymeric substances (EPSs), which are one of the main causes of membrane fouling in MBRs (Duan et al., 2013; Le-Clech et al., 2006; Leiknes et al., 2006). Importantly, so far, no research has been conducted on the performance of the RPS with respect to enhanced denitrification and on the combination of the RPS and MBR to improve the overall removal efficiency of pollutants in sewage, reduce sludge production, and alleviate fouling to produce high-quality effluents. Furthermore, this study was conducted using a pilot plant under actual conditions to accurately reflect the research problem, which laboratory or bench experiments or experiments based on synthetic wastewater do not reflect.

Our goal was to understand the combined advantages of a hybrid pilot plant regarding sewage treatment and the role of the RPS in nitrogen removal and reduced membrane fouling. The main objectives of this study were: i) to evaluate the ability of the system to remove organics and nutrients for the production of a high-quality effluent; ii) to assess the nitrification and denitrification performances of the MBR and RPS, respectively; iii) to monitor and analyze the filtration performance and fouling behavior of the MBR during operation; and iv) based on the findings, to provide factors essential for the execution, design, operation, and improvement of existing treatment technologies.

\section{Materials and methods}

\subsection{Wastewater characteristics}

The study was conducted using sewage from the influent of a full-scale sewage treatment plant (STP) in Yongmun City, South Korea. The characteristics of the feed wastewater obtained throughout this study are shown in Table 1.

\subsection{Experimental setup}

The new large hybrid pilot plant consists of a buffer tank (BT, $\left.1 \mathrm{~m}^{3}\right)$, which stabilizes the influent concentration and load, modularized rolled pipe system (RPS, $4 \mathrm{~m}^{3}$ ), and membrane bioreactor (MBR, $15 \mathrm{~m}^{3}$ of effective volume). The system was designed and installed at the full-scale STP in Yongmun City, South Korea. It was operated continuously for more than four months to treat 
constant influent flow (Q) of $30 \mathrm{~m}^{3} / \mathrm{d}$. The schematic diagram and photos of the hybrid system are shown in Fig. 1 and Supplementary Material Fig. S1.

Table 1. Characteristics of the feed wastewater (All concentrations are in $\mathrm{mg} / \mathrm{L}$, except for the $\mathrm{pH}$ ).

\begin{tabular}{llll}
\hline \multirow{2}{*}{ Analytical parameter } & \multicolumn{3}{l}{ Raw wastewater } \\
\cline { 2 - 4 } & Min. & Max. & Aver. \pm Std. \\
\hline pH & 6.73 & 7.98 & $7.51 \pm 0.34$ \\
Suspended solids, SS & 60 & 355.00 & $109.56 \pm 49.73$ \\
Total chemical oxygen demand, TCODCr & 35.4 & 174.00 & $105.23 \pm 33.79$ \\
Soluble chemical oxygen demand, SCODCr & 29 & 141.50 & $78.83 \pm 27.97$ \\
Total nitrogen, $\mathrm{TN}$ & 9.28 & 29.46 & $20.36 \pm 5.00$ \\
Nitrate nitrogen, $\mathrm{NO}_{3}{ }^{-}-\mathrm{N}$ & 0.1 & 2.40 & $0.60 \pm 0.37$ \\
Ammonia nitrogen, $\mathrm{NH}_{4}-\mathrm{N}$ & 5.33 & 24.05 & $16.33 \pm 4.30$ \\
Orthophosphate, $\mathrm{PO}_{4}{ }^{3-}-\mathrm{P}$ & 0.7 & 3.90 & $2.50 \pm 0.74$ \\
Alkalinity as CaCO, Alk. & 58 & 126.00 & $105.65 \pm 15.55$ \\
\hline
\end{tabular}

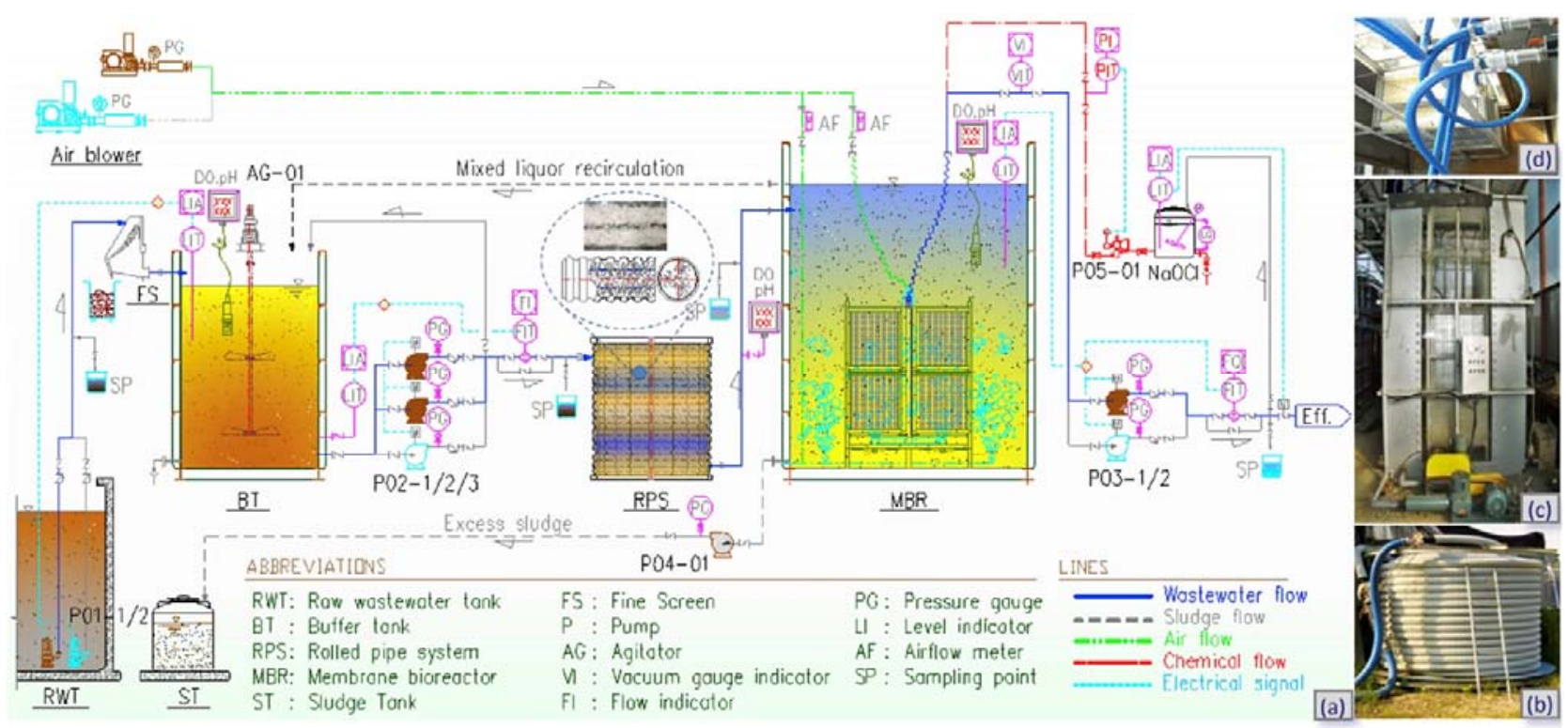

Fig. 1. Schematic showing flows, elements, and connections of the RPS-MBR hybrid system (a); photos of the rolled pipe system (b), membrane bioreactor (c), and membrane filtration (d).

The influent wastewater was pumped from the influent of the STP through a fine screen with 0.5$1.0 \mathrm{~mm}$ openings prior to entering the continuously mixed buffer tank (BT) using two alternating submersible pumps (Wilo Pump, South Korea) to remove debris, hair, fibrous materials, and other large-particle granular material that can cause damage to system components (e.g., pumps, membrane, and mixers). The wastewater in the buffer tank was continuously mixed using a mixer to homogenize the contents. The wastewater from the buffer tank was fed to the RPS by using three lift pumps (Wilo Pump, South Korea) prior to flowing into the MBR in which two flat-sheet membrane modules were submerged. Subsequently, the treated effluent stream was discharged by 
two alternating suction pumps. The internal recycling (IR) of the mixed liquor from the MBR to the buffer tank was performed using free flow (Fig. 1).

The modularized RPS in this study was a tubular-type continuous plug flow system including a corrugated high-density polyethylene (HDPE) pipe system (inside diameter $100 \mathrm{~mm}$, length $500 \mathrm{~m}$ ) with three braided nylon ropes (rope biofilter media). Around each rope, a flexible fiber bundle was woven to enable the growth of the attached denitrifiers (Fig. 1b). The total rope media introduced into the pipe accounted for $30 \% \pm 5 \%$ of the total effective volume of the RPS, with a specific surface area in the range of $52.5-67.97 \mathrm{~m}^{2} / \mathrm{m}$ of the pipe.

Two immersed flat sheet membrane modules (Pure Envitech Co., Ltd, South Korea) were used to separate the solids and liquids in the MBR. The membranes had a total effective filtering surface area for mass transfer of $98 \mathrm{~m}^{2}\left(0.98 \mathrm{~m}^{2}\right.$ per membrane element) and each membrane module consisted of 50 sheets of membrane element with a nominal membrane pore size ranging from 0.1 to $0.4 \mu \mathrm{m}(0.14 \mu \mathrm{m}$ average). The transmembrane pressure (TMP) and permeate flux were designed and operated in the range of the $0-40 \mathrm{~cm} \mathrm{Hg}$ and $0.3-0.5 \mathrm{~m}^{3} /\left(\mathrm{m}^{2} \mathrm{~d}\right)$, respectively. The membranes were operated using a 10 -min filtration cycle including $8 \mathrm{~min}$ filtration and $2 \mathrm{~min}$ relaxation.

Two industrial rotary air blowers (Hwang Hae Electric Co., Ltd, South Korea) operated alternately and continuously supplied air at a flow rate of $1.2 \mathrm{~m}^{3}$ air per minute to the bottom of the MBR in which $75 \%$ of the air flow was introduced into the coarse-bubble air diffuser system. The air diffuser was installed under the membrane modules such that the sludge flowed upwards through the membrane to improve scouring of the membrane surface and contact between microorganisms and contaminants and to maintain a sufficient level of dissolved oxygen in the reactor for bioactivity (Nguyen et al., 2014a, b). The remaining air flow (25\%) was introduced into another air distribution system, which was installed outside the membrane module to avoid creating dead zones and to improve the oxygen mass transfer. Furthermore, all devices of the pilot system (e.g., pumps, air blowers, mixers, pressure gauges, and level sensors) were automatically controlled and operated at the desired values using the programmable logic controller.

\subsection{Operating procedures and conditions}

The experiment was conducted in two operation modes (modes 1 and 2) that differed by hydraulic retention times (HRTs) and internal recycle (IR) ratios from the MBR to the buffer tank based on the influent flow rate $(\mathrm{Q})$. The operating conditions were extensively tested prior to conducting the experiment. The HRT of the RPS and MBR in mode 1 were $60 \mathrm{~min}$ and $6 \mathrm{~h}$, respectively, equivalent to an IR ratio of 1 . The HRT of the RPS and MBR in mode 2 were $42 \mathrm{~min}$ and $4 \mathrm{~h}$, respectively, with an IR ratio of 2 . The MBR was seeded with $12 \mathrm{~m}^{3}$ of activated sludge obtained from the STP; subsequently, the system was operated to reestablish its steady state.

The system reached the designated stages when the concentration of dissolved oxygen (DO) was greater than $3 \mathrm{mg} / \mathrm{L}$ and that of mixed liquor suspended solids (MLSS) in the MBR was approximately $5500 \mathrm{mg} / \mathrm{L}$. The DO concentration in the RPS depends on the IR ratio and was kept as low as possible (less than $0.5 \mathrm{mg} / \mathrm{L}$ is optimal for denitrification). Surplus sludge was removed daily from the MBR and ranged from 72 to $108 \mathrm{~L}$, corresponding to $0.24 \%-0.36 \%$ of the total influent flow. Sludge removal was required to maintain a proper MBR biomass concentration of 
approximately $5500 \mathrm{mg}$ MLSS per liter. The system was in start-up operation for over a month to establish proper conditions for microorganism growth at a starting flow rate of approximately $16 \mathrm{~m}^{3} / \mathrm{d}$ (equal to $50 \%$ of the design flow), which then was gradually increased to reach the design flow. Initially, $75 \%$ of the membrane tank volume was seeded by active biomass, which was collected from the aeration tank.

\subsection{Sampling and analysis}

To assess and compare the overall performance of the hybrid system under different running modes, all wastewater quality samples of the influent and effluent and samples from each tank were collected 1-5 times per week throughout the study period and analyzed immediately after sampling. The quality parameters of the RPS samples obtained from the RPS output point were analyzed. All protocols for sampling, preservation, and storage were followed. To determine soluble parameters, the samples were filtered through a $0.2 \mu \mathrm{m}$ Whatman $\mathrm{GC} / \mathrm{C}$ glass microfiber filter to remove any residuals such as biomass and inorganic particles.

The chemical oxygen demand $\left(\mathrm{COD}_{\mathrm{Cr}}\right)$, total nitrogen $(\mathrm{TN})$, ammonia nitrogen $\left(\mathrm{NH}_{4}{ }^{+}-\mathrm{N}\right)$, nitrate nitrogen $\left(\mathrm{NO}_{3}{ }^{-}-\mathrm{N}\right)$, total suspended solids (TSS), MLSS, total phosphorus (TP), orthophosphate $\left(\mathrm{PO}_{4}{ }^{3-}-\mathrm{P}\right)$, and alkalinity were analyzed according to standard methods described in APHA et al. (2003) and Nguyen et al. (2014b). The pH values were measured using a CyberScan pH $510 \mathrm{~m}$ (Thermo Fisher Scientific Inc., US). The temperature and DO concentrations were monitored using a YSI 550 Dissolved Oxygen Meter (YSI Environmental, US). The alkalinity was determined by titration using a solution of $0.02 \mathrm{~N} \mathrm{H}_{2} \mathrm{SO}_{4}$.

\subsection{Calculated parameters}

The COD and TN volumetric loading rates were calculated using Eq. (1):

$$
L R=\frac{Q_{\text {inf }} \times S_{o}}{\left(V_{R P S}+V_{\mathrm{MBR}}\right)}
$$

where LR is the volumetric loading rate of the COD or TN, $\mathrm{kg} /\left(\mathrm{m}^{3} \mathrm{~d}\right)$; Qinf is the influent wastewater flow rate, $\mathrm{m}^{3} / \mathrm{d}$; $\mathrm{S}_{\mathrm{o}}$ is the influent COD or TN concentration, $\mathrm{g} / \mathrm{m}^{3}$; and $\mathrm{V}_{\mathrm{RPS}}$ and $\mathrm{V}_{\mathrm{MBR}}$ are the total volumes of the RPS and MBR, respectively, $\mathrm{m}^{3}$.

The food to biomass (F/M) ratio of the hybrid system was calculated with Eq. (2):

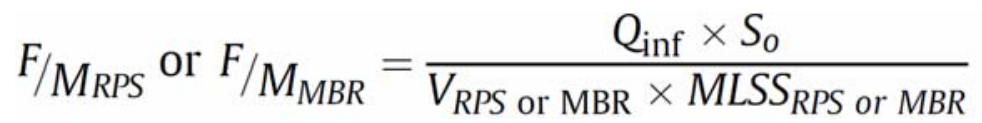

where $\mathrm{F} / \mathrm{M}$ is the food to biomass ratio, $\mathrm{g} \mathrm{COD} /(\mathrm{g}$ MLSS $\cdot \mathrm{d}) ; \mathrm{MLSS}_{\mathrm{RPS}}$ and MLSS $\mathrm{MBR}$ are the concentrations of the mixed liquor biomass in the RPS or MBR, gMLSS $/ \mathrm{m}^{3}$; and $\mathrm{S}_{\mathrm{o}}$ is the COD of RPS or MBR, $\mathrm{g} / \mathrm{m}^{3}$.

The nitrification rate (NR) and denitrification rate (DNR) were calculated based on Eqs (3) and (4), respectively. 


$$
N R=\frac{Q_{\text {inf }}}{V_{M B R}} \times \frac{\left(N_{4}^{+}-N_{\text {inf }}-N H_{4}^{+}-N_{e f f}\right)}{M L V S S_{M B R}}
$$

where $\mathrm{NH}_{4}{ }^{+}-\mathrm{N}_{\text {inf. }}$ And $\mathrm{NH}_{4}{ }^{+}-\mathrm{N}_{\text {eff. }}$ Are the influent and effluent ammonia nitrogen concentrations, $\mathrm{mg} / \mathrm{L}$; $\mathrm{TN}$ inf. And $\mathrm{TN}_{\text {eff }}$ are the influent and effluent total nitrogen concentrations, $\mathrm{mg} / \mathrm{L}$; and MLVSS $_{R P S}$ and MLVSS ${ }_{M B R}$ are the mixed liquor volatile suspended solids in RPS and MBR, respectively, $\mathrm{mg} / \mathrm{L}$.

$$
D N R=\frac{Q_{\text {inf }}}{V_{R P S}} \times \frac{\left(T N_{\text {inf }}-T N_{\text {eff }}\right)}{M L V S S_{R P S}}
$$

\section{Results and discussion}

\subsection{System monitoring parameters}

To analyze the effects of the operation strategy on the pollutant removal and membrane fouling in the system, the variations in temperature, $\mathrm{pH}$, alkalinity, DO, and MLSS in the influent, effluent, and each work unit of the process were monitored and evaluated throughout the operation (Fig. 2, and Table 2 and Supplementary Material Table S1).
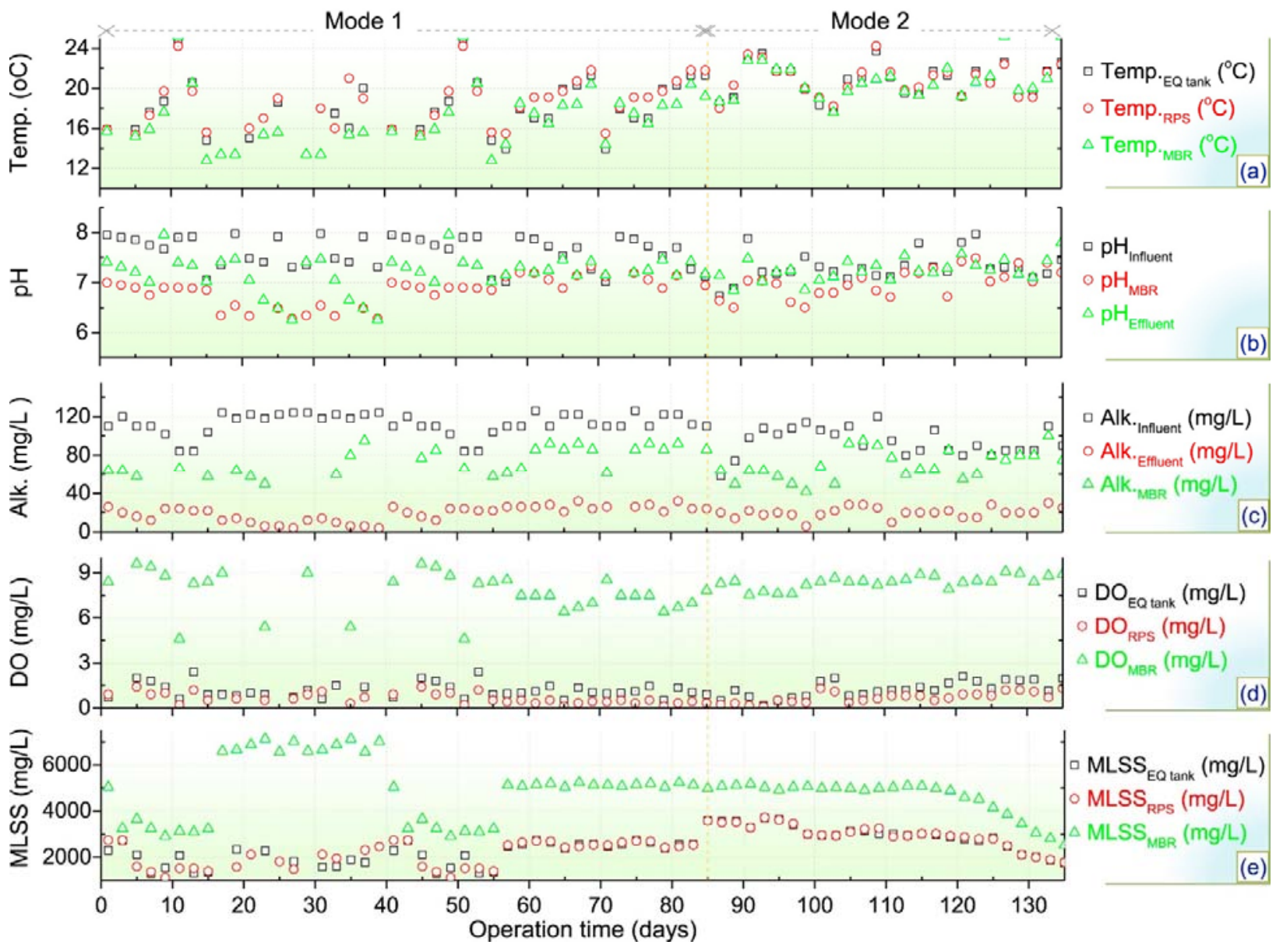

Fig. 2. Variations in the temperature, $\mathrm{pH}$, alkalinity, DO, and MLSS in each working unit of the hybrid biological treatment system during operation. 
Table 2. Average values and standard deviations of temperature, $\mathrm{pH}$, alkalinity, $\mathrm{DO}$, and $\mathrm{SS}$ during the operational periods.

\begin{tabular}{|c|c|c|c|c|c|c|}
\hline \multirow{2}{*}{ Parameters } & \multirow{2}{*}{ Units } & \multicolumn{5}{|c|}{ Sampling points } \\
\hline & & Influent & Buffer tank & RPS & MBR & Effluent \\
\hline \multicolumn{7}{|l|}{ Mode 1} \\
\hline $\mathrm{pH}$ & - & $7.64 \pm 0.30$ & - & - & $6.83 \pm 0.30$ & $7.18 \pm 0.37$ \\
\hline Temp. & ${ }^{\circ} \mathrm{C}$ & $18.37 \pm 3.09$ & $18.124 \pm 2.72$ & $18.560 \pm 2.42$ & $16.928 \pm 3.01$ & $17.144 \pm 3.00$ \\
\hline DO & $\mathrm{mg} / \mathrm{L}$ & $1.07 \pm 1.67$ & $1.17 \pm 0.496$ & $0.63 \pm 0.360$ & $8.12 \pm 1.802$ & $8.05 \pm 1.99$ \\
\hline MLSS & $\mathrm{mg} / \mathrm{L}$ & - & $2123.24 \pm 499.25$ & $2101.05 \pm 558.87$ & $4974.29 \pm 1437.49$ & - \\
\hline Alk. & $\mathrm{mg} / \mathrm{L}$ & $112.57 \pm 11.62$ & - & - & $73.71 \pm 14.16$ & $18.93 \pm 8.05$ \\
\hline \multicolumn{7}{|l|}{ Mode 2} \\
\hline $\mathrm{pH}$ & - & $7.31 \pm 0.29$ & - & - & $7.00 \pm 0.28$ & $7.25 \pm 0.22$ \\
\hline Temp. & ${ }^{\circ} \mathrm{C}$ & $20.54 \pm 2.18$ & $20.812 \pm 1.61$ & $20.90 \pm 1.59$ & $20.712 \pm 1.84$ & $20.90 \pm 1.78$ \\
\hline DO & $\mathrm{mg} / \mathrm{L}$ & $0.14 \pm 0.04$ & $1.25 \pm 0.544$ & $0.69 \pm 0.363$ & $8.36 \pm 0.432$ & $8.57 \pm 0.45$ \\
\hline MLSS & $\mathrm{mg} / \mathrm{L}$ & & $2938.08 \pm 531.53$ & $2950.77 \pm 528.82$ & $4588.85 \pm 778.82$ & - \\
\hline Alk. & $\mathrm{mg} / \mathrm{L}$ & $94.46 \pm 14.70$ & - & - & $70.40 \pm 15.50$ & $20.31 \pm 5.52$ \\
\hline
\end{tabular}

The wastewater temperature ranged from $12.8^{\circ} \mathrm{C}$ to $25.9^{\circ} \mathrm{C}$. The average wastewater temperatures in the buffer tank, RPS, and MBR were $18.12^{\circ} \mathrm{C}$ [Standard deviation (Std) $\pm 2.72{ }^{\circ} \mathrm{C}$ ], $18.56{ }^{\circ} \mathrm{C} \pm 2.42{ }^{\circ} \mathrm{C}$, and $16.93{ }^{\circ} \mathrm{C} \pm 3.01{ }^{\circ} \mathrm{C}$ in mode 1 and $20.81{ }^{\circ} \mathrm{C} \pm 1.61{ }^{\circ} \mathrm{C}, 20.90{ }^{\circ} \mathrm{C} \pm 1.59{ }^{\circ} \mathrm{C}$, and $20.71^{\circ} \mathrm{C} \pm 1.84{ }^{\circ} \mathrm{C}$ in mode 2, respectively (Fig. 2a). The wastewater temperature is one of the parameters markedly inhibiting the growth rate of microbial populations in a biological treatment system. Although this has been reported in the literature, there is a lack of consistency in the reports with regard to the level of influence of the temperature (Guo et al., 2013; Kim et al., 2006). However, a clear impact was observed when the temperature dropped below $10^{\circ} \mathrm{C}$ (Ilies and Mavinic, 2001), particularly affecting the bioactivities of nitrifying and denitrifying bacteria and consequently significantly reducing the overall system performance.

Alkalinity plays a role in maintaining the activities and growth of autotrophic nitrifying bacteria (nitrifiers) for nitrification (Nguyen et al., 2014a). In this study, the average alkalinity of the influent, MBR, and effluent were $105.647 \pm 15.55,72.089 \pm 14.79$, and $19.463 \pm 7.16 \mathrm{mg} / \mathrm{L}$ $\left(\mathrm{CaCO}_{3}\right)$, respectively (Fig. 2c), while the $\mathrm{pH}$ values remained in a neutral range from 6.73 to 7.98 without adding any chemicals and were $7.64 \pm 0.30$ in the influent and $7.18 \pm 0.37$ in the effluent (Fig. 2b). Thus, the results show that the alkalinity has sufficient buffering capacity in the MBR such that the biological process can take place in a normal manner.

The average DO concentrations were controlled and maintained at the design values in the buffer tank, RPS, and MBR, that is, in the $1-1.5 \mathrm{mg} / \mathrm{L}$ range, lower than $0.8 \mathrm{mg} / \mathrm{L}$, and higher than $2 \mathrm{mg} / \mathrm{L}$, respectively, corresponding to monitoring values of $1.206 \pm 0.51,0.655 \pm 0.36$, and $8.222 \pm 1.4 \mathrm{mg} / \mathrm{L}$, respectively (Fig. 2d). High levels of DO are maintained in the MBR to: firstly, maximize metabolic substrates (enhancing organic removal and nitrification performances) (Riffat, 2012; Sriwiriyarat et al., 2008); secondly, minimize excess sludge production; and thirdly, reduce extracellular polymeric substances (EPS) (Abbassi et al., 2000). Therefore, mitigated membrane fouling occurs in all cases (Geng and Hall, 2007), which is one of the main limitations preventing 
widespread applications of the membrane process in wastewater treatment plants. In addition, to ensure that the MLSS in the work unit were as designed and to extend the time for the chemical cleaning cycle of the membrane (Nguyen et al., 2014a), excess sludge (72-108 L) was discharged daily from the MBR. The average MLSS concentrations in the buffer tank, RPS, and MBR were 2123.24 $\pm 499.25,2101.05 \pm 558.87$, and $4974.29 \pm 1437.49 \mathrm{mg} / \mathrm{L}$, respectively, in mode 1 , and $2938.08 \pm 531.53,2950.77 \pm 528.82$, and $4588.85 \pm 778.82 \mathrm{mg} / \mathrm{L}$, respectively, in mode 2 (Fig. 2e).

Moreover, all parameters (temperature, $\mathrm{pH}$, alkalinity, DO, and MLSS) were associated with degradation parameters of water quality indexes ( $\mathrm{COD}, \mathrm{TN}, \mathrm{NH}_{4}{ }^{+}-\mathrm{N}, \mathrm{NO}_{3}{ }^{-}-\mathrm{N}, \mathrm{TP}, \mathrm{PO}_{4}{ }^{3-}-\mathrm{P}$, etc.) in every unit to assess their relationships and roles in the performance of each working unit and the entire hybrid system.

\subsection{SS and COD removal efficiency and membrane performance under different modes}

Fig. $3 \mathrm{a}$ and $\mathrm{b}$ shows the variations of SS, COD, and soluble chemical oxygen demand (SCOD) concentrations in the influent and effluent and the overall removal efficiency for different operating modes throughout the study. The COD loading rate and F/M ratio of the RPS and MBR are illustrated in Fig. $3 \mathrm{c}$ and d.
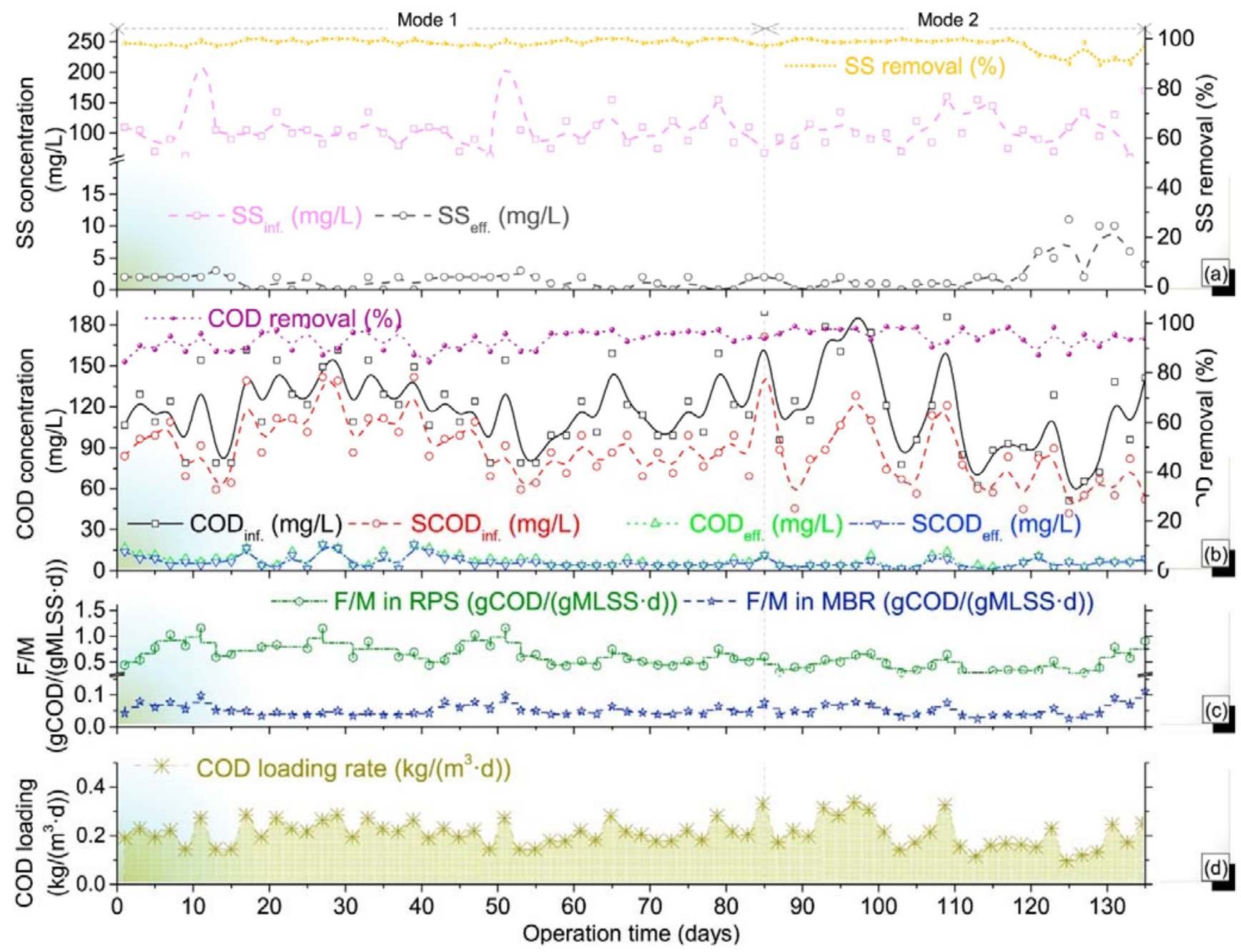

Fig. 3. Variations of the SS, COD, COD loading rate, and F/M ratio in the hybrid biological treatment system during operation. 
Fig. $3 \mathrm{a}$ and $\mathrm{b}$ shows that the hybrid system produces an excellent water quality of the effluent and the production is relatively steady, although the influent SS, total COD concentrations, and COD loading rate fluctuate widely between 60 and $350 \mathrm{mg} \mathrm{SS} / \mathrm{L}, 50.9$ and $192.8 \mathrm{mg} \mathrm{COD} / \mathrm{L}$, and 0.09 and $0.33 \mathrm{~kg} \mathrm{COD} /\left(\mathrm{m}^{3} \mathrm{~d}\right)$, respectively. The final concentrations in the effluent remain relatively low at $1.84 \pm 2.28 \mathrm{mg} \mathrm{SS} / \mathrm{L}, 7.18 \pm 4.68 \mathrm{mg} \mathrm{COD} / \mathrm{L}$, and $6.63 \pm 4.67 \mathrm{mg} \mathrm{SCOD} / \mathrm{L}$, irrespective of the IR (modes 1 or 2). The concentration ratio of SCOD per total COD (SCOD/COD) in the influent varies between 0.36 and 0.97 (average $0.76 \pm 0.15$ ) and the $\mathrm{F} / \mathrm{M}$ ratio varies between 0.21 and $1.16 \mathrm{~g} \mathrm{COD} /(\mathrm{g}$ MLSS $\cdot \mathrm{d}$ ) [average of $0.59 \pm 0.23 \mathrm{~g} \mathrm{COD} /(\mathrm{g}$ MLSS $\cdot \mathrm{d})$ ] in the RPS and between 0.02 and $0.11 \mathrm{~g} \mathrm{COD} /(\mathrm{g} \mathrm{MLSS} \cdot \mathrm{d}$ ) [average of $0.05 \pm 0.02 \mathrm{~g} \mathrm{COD} /(\mathrm{g}$ MLSS $\cdot \mathrm{d})$ ] in the MBR (Fig. 2c).

The average SS concentrations in the effluent in modes 1 and mode 2 remains at $1.24 \pm 1.03 \mathrm{mg} / \mathrm{L}$, and $2.81 \pm 3.25 \mathrm{mg} / \mathrm{L}$, respectively, corresponding to average SS removal efficiencies of $98.73 \% \pm 1.15 \%$ and $97.16 \% \pm 3.42 \%$, respectively. Meanwhile the average COD removal efficiency of the system is $92.82 \% \pm 4.08 \%$, while the residual COD and SCOD values of the final effluent are $8.29 \pm 4.89 \mathrm{mg} \mathrm{COD} / \mathrm{L}$ and $6.83 \pm 4.71 \mathrm{mg} \mathrm{SCOD} / \mathrm{L}$, respectively, in mode 1 . The average COD removal efficiency of the system in mode 2 slightly increases to $95.08 \% \pm 3.38 \%$ and the residual COD and SCOD values of the final effluent are $5.40 \pm 3.77 \mathrm{mg} \mathrm{COD} / \mathrm{L}$ and $5.08 \pm 3.16 \mathrm{mg} \mathrm{SCOD} / \mathrm{L}$, respectively. These results indicate that using the membrane ensured a consistent effluent quality, with a significant barrier to effectively retain biomass, solids, and all other particle fractions in the MBR. Moreover, a proper biomass concentration was maintained in the MBR.

Despite wide fluctuations of the influent concentrations, the hybrid system operates robustly and efficiently and nearly all organic compounds are degraded and transformed ( $>97 \%$ SS and $>92 \%$ COD removals) without inhibiting the process. Moreover, the removal of SS or COD in the two operating modes does not significantly differ; average effluent concentrations below $3 \mathrm{mg} \mathrm{SS} / \mathrm{L}$ and $8.5 \mathrm{mg} \mathrm{COD} / \mathrm{L}$ are maintained in the system. Consequently, the effluent quality of domestic sewage treated with this technology is considerably better than that specified in South Korean regulations regarding domestic wastewater quality standards for effluents $(<40 \mathrm{mg} \mathrm{COD} / \mathrm{L}$ and $20 \mathrm{mg} \mathrm{SS} / \mathrm{L}$ ). The average phosphate removal efficiencies achieved in modes 1 and 2 are 49.18\% and $34.83 \%$, respectively, corresponding to concentrations of $1.38 \pm 0.51 \mathrm{mg} / \mathrm{L}$ and $1.49 \pm 0.38 \mathrm{mg} / \mathrm{L}$, respectively, remaining in the effluent. Generally, the phosphate removal efficiency is not as good as the COD removal in this system because only biological treatment was applied. This means that only a portion of the phosphate is synthesized and accumulated in the microbial biomass in the sludge and the phosphate removal is achieved by the disposal of excess sludge containing rich phosphate (de-Bashan and Bashan, 2004; Yang et al., 2010). Therefore, to obtain a greater phosphate removal efficiency, this system should be combined with other methods such as precipitation (de-Bashan and Bashan, 2004), adsorption (Zheng et al., 2016), electrocoagulation (Nguyen et al., 2016), or chemical processes (Ye et al., 2016).

\subsection{Nitrification and denitrification efficiencies and total nitrogen removal}

To improve the efficiency and rate of biological nitrogen transformation/removal, the hybrid treatment process was designed as a two-stage treatment combining MBR and the original RPS to assure favorable conditions for the growth and activity of ammonia-oxidizing bacteria (aerobic nitrification) and nitrite-oxidizing bacteria (anoxic denitrification), respectively. 
The nitrification process was carried out in the MBR. Ammonia nitrogen is first oxidized to nitrite and then to nitrate by aerobic autotrophic bacteria. Along with nitrification, a portion of ammonia is assimilated into the cell tissue (synthesis) (Riffat, 2012). Subsequently, nitrate is converted into nitrogen gas by nitrite-oxidizing (denitrifying) bacteria consuming organic substrates in wastewater as the electron donor under anoxic conditions in the RPS, known as denitrification process (Fulazzaky et al., 2015). In this study, the ratio of ammonia nitrogen to total nitrogen of the wastewater feeding varied from $70 \%$ to $100 \%$ (average $84.03 \% \pm 5.64 \%$ ), indicating that most of the nitrogen existed in the form of ammonia.

During all run periods, the hybrid system operated under unstable and relatively low influent wastewater temperatures, which varied considerably between $13.10^{\circ} \mathrm{C}$ and $25.9{ }^{\circ} \mathrm{C}$ (Fig. 2a). Moreover, the influent wastewater contained a wide range of nutrients and organic pollutants. However, the average TN removal efficiency was greater than $60 \%$ (average $\mathrm{TN}<8.77 \mathrm{mg} / \mathrm{L}$ ), at a TN loading rate range of $0.028-0.050 \mathrm{~kg} \mathrm{TN} /\left(\mathrm{m}^{3} \mathrm{~d}\right)$ and an organic loading rate range of $0.087-$ $0.328 \mathrm{~kg} \mathrm{COD} /\left(\mathrm{m}^{3} \mathrm{~d}\right)$ (Figs. 3 and 4$)$.

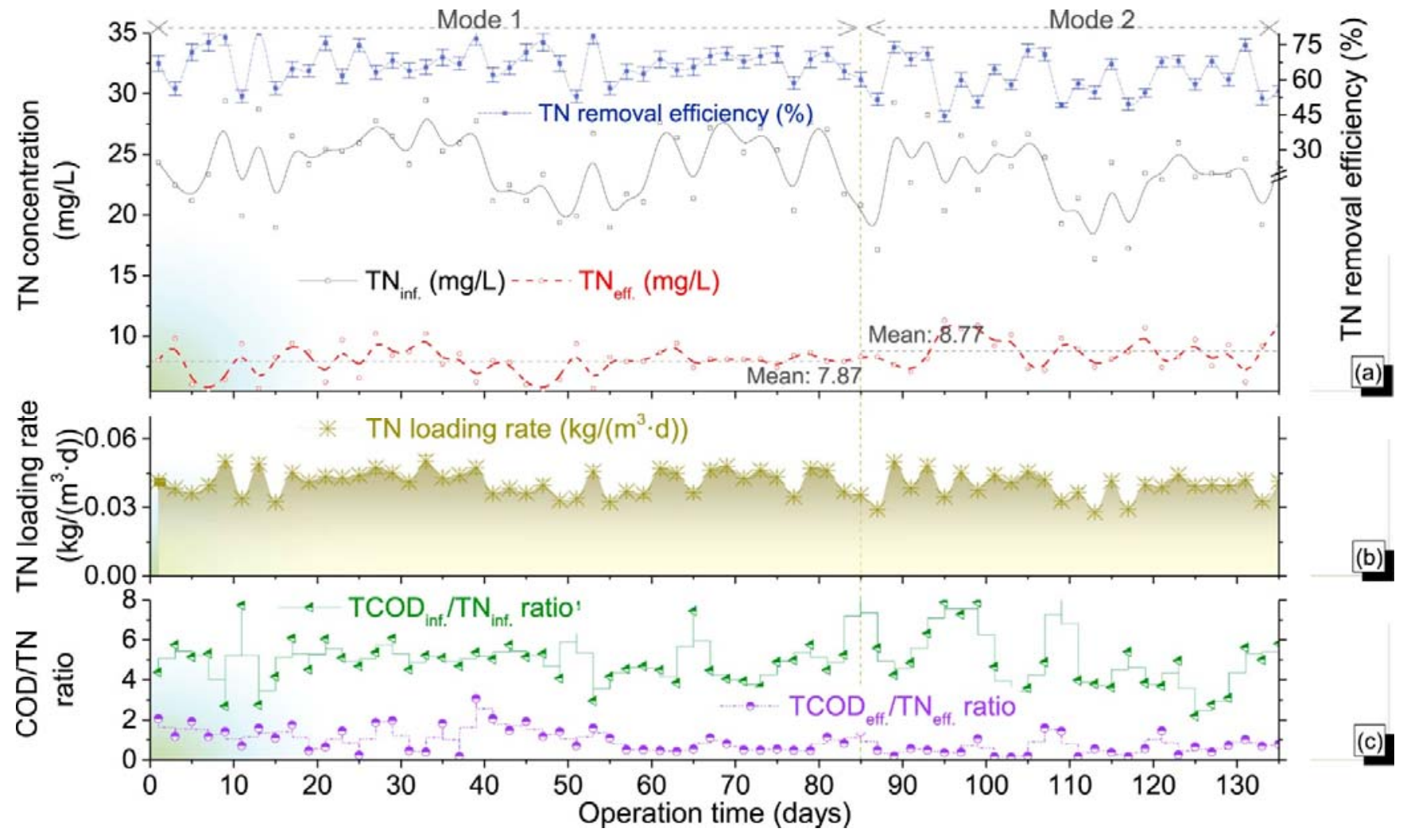

Fig. 4. Variations of the $\mathrm{TN}$, $\mathrm{TN}$ loading rate, and $\mathrm{COD} / \mathrm{TN}$ ratio in the hybrid biological treatment system during operation.

Under modes 1 and 2 operating conditions, with average influent COD/TN ratios of $4.94 \pm 1.11$ and $5.11 \pm 1.92$, respectively (Fig. 4c), an average TN removal of $67.18 \% \pm 6.86 \%$ and $60.91 \% \pm 8.73 \%$, respectively, was achieved, corresponding to $\mathrm{TN}$ concentrations of $7.87 \pm 1.31 \mathrm{mg} / \mathrm{L}$ and $8.77 \pm 1.40 \mathrm{mg} / \mathrm{L}$, respectively, remaining in the effluent (Fig. $4 \mathrm{a}$ ). This 
indicates that the results obtained for TN are significant when compared with the effluent standard of less than $10 \mathrm{mg} \mathrm{TN} / \mathrm{L}$.

Although the results indicate nearly complete nitrification to nitrate in the MBR for both modes, the conversion efficiency of ammonia nitrogen is in the range of $98.18 \%-99.68 \%$ in mode 1 versus $98.32 \%-99.70 \%$ in mode 2 (Fig. 5a). However, the denitrification rate of the RPS in mode 1 is $116.95 \pm 46.12 \mathrm{mg} \quad \mathrm{NO}_{3}-\mathrm{N} /(\mathrm{g}$ MLVSS$\cdot \mathrm{d})$ compared with only $68.80 \pm 22.24 \mathrm{mg} \quad \mathrm{NO}_{3}-\mathrm{N} /(\mathrm{g}$ MLVSS $\cdot d$ ) in mode 2 (Fig. 6b). This confirms that the nitrogen removal by the hybrid system is better in mode 1 than in mode $2(67.18 \%$ vs. $60.91 \%$; Fig. $4 a)$. The COD removal is slightly lower in mode 1 than in mode 2 (92.82\% vs. $95.08 \%$; Fig. 3 b).

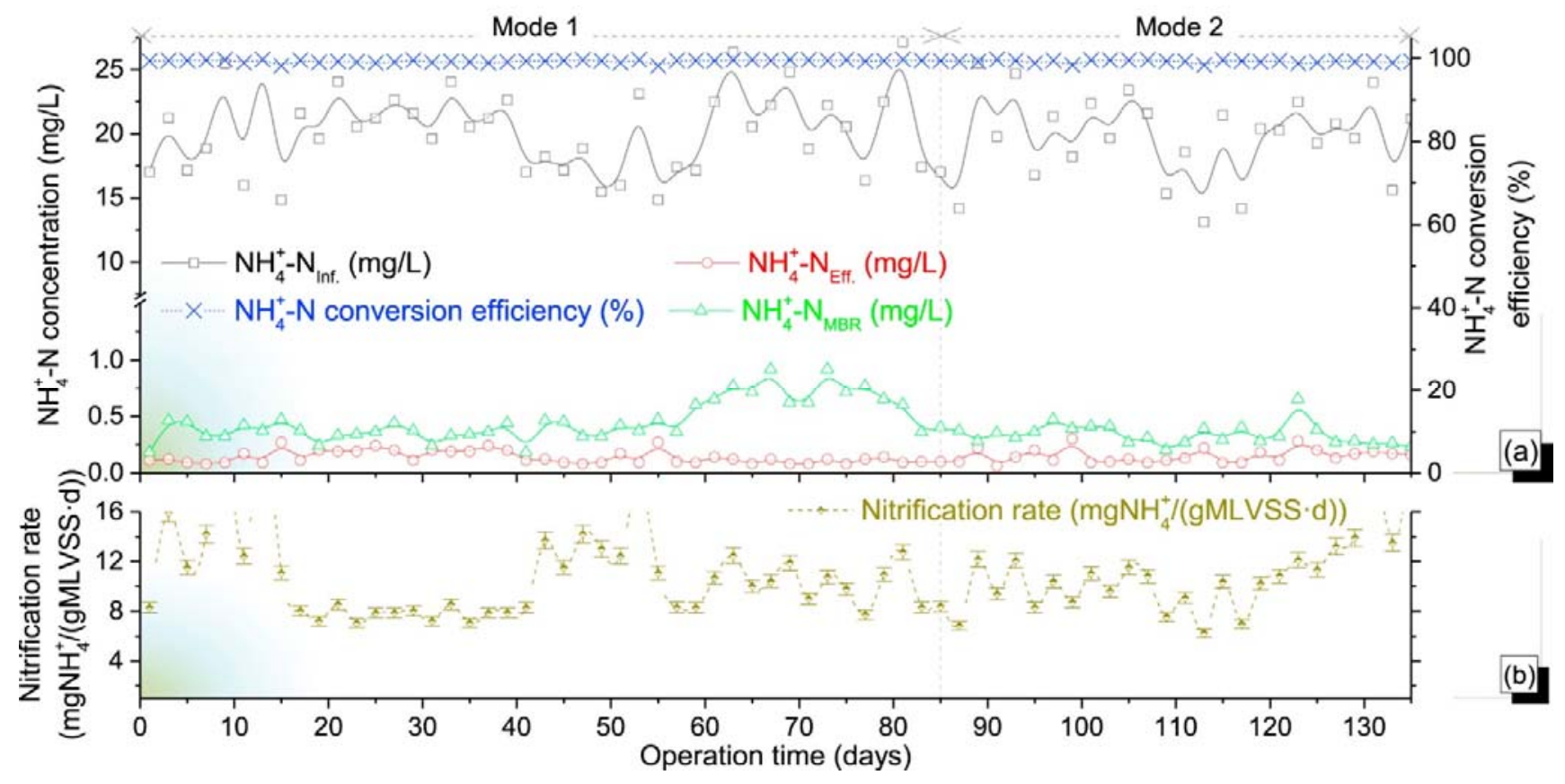

Fig. 5. Variations of the $\mathrm{NH}_{4}{ }^{+}-\mathrm{N}$ and $\mathrm{NH}_{4}{ }^{+}-\mathrm{N}$ conversion efficiencies and nitrification rate in the hybrid biological treatment system during operation.

The results also indicate that the average nitrification rates are $10.82 \pm 3.63 \mathrm{mg} \mathrm{NH} /(\mathrm{g} \mathrm{MLVSS} \cdot \mathrm{d})$ in mode 1 and $10.94 \pm 3.35 \mathrm{mg} \mathrm{NH}_{4} /(\mathrm{g} \mathrm{MLVSS} \cdot \mathrm{d})$ in mode 2 , while the average ammonia nitrogen concentration in all modes is low (less than $0.15 \mathrm{mg} / \mathrm{L} ; 99.2 \%$ of the $\mathrm{NH}_{4}^{+}-\mathrm{N}$ conversion efficiency). Interestingly, although the MBR was operated in different modes with different hydraulic retention times, the results indicate that both operating conditions result in similar and excellent ammonia conversion efficiencies. This is attributed mainly to the operating conditions of the MBR, that is, high average biomass levels $(4826.9 \pm 1235.49 \mathrm{mg} \mathrm{MLSS} / \mathrm{L})$ and DO concentrations $(8.22 \pm 1.4 \mathrm{mg} \mathrm{DO} / \mathrm{L})$ during the entire study period. Therefore, it can be concluded that the MBR should be maintained at high concentrations of DO and biomass if the HRT in the MBR is short (e.g., $4 \mathrm{~h}$ ) to achieve a high efficiency in the conversion of ammonia nitrogen into nitrate. However, operating the MBR at too high concentrations of biomass ( $>15 \mathrm{~g}$ MLSS/L) and DO is not recommended because it might cause or contribute to faster membrane fouling (Choi and $\mathrm{Ng}, 2008$; Rosenberger et al., 2005) and an increased energy demand for total aeration. 


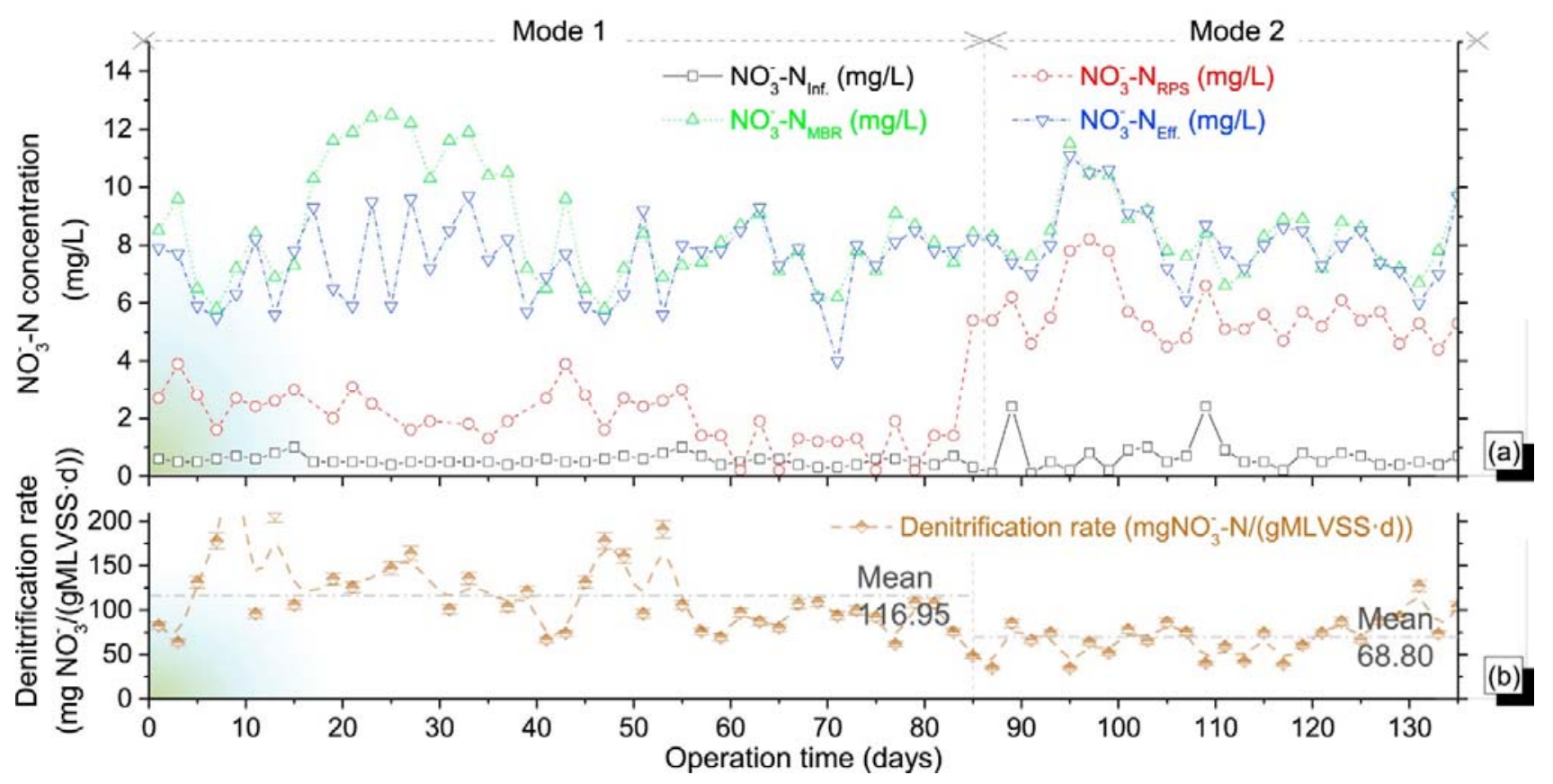

Fig. 6. Variations of the $\mathrm{NO}_{3}{ }^{-}-\mathrm{N}$ and denitrification ratio in the hybrid biological treatment system during operation.

The denitrification performance of the RPS is shown in Fig. 6. Although the IR of the mixed liquor from the nitrification stage of the MBR to the denitrification stage of the RPS is lower in mode 1 (IR: $100 \%$ ) than in mode 2 (IR: 200\%), the denitrification rate of mode 1 is $116.95 \pm 46.12 \mathrm{mg}$ $\mathrm{NO}_{3}-\mathrm{N} /(\mathrm{g}$ MLVSS$\cdot \mathrm{d})$, that is, higher than that in mode $2[68.80 \pm 22.24 \mathrm{mg} \mathrm{NO}-\mathrm{N} /(\mathrm{g} \mathrm{MLVSS} \cdot \mathrm{d})]$. These values correspond to nitrate concentrations of $1.97 \pm 0.94 \mathrm{mg} / \mathrm{L}$ (mode 1) and $5.61 \pm 1.01 \mathrm{mg} / \mathrm{L}$ (mode 2) remaining after treatment (passage through) by the RPS. This indicates that the denitrifying efficiency is much lower in mode 2 than in mode 1 . This difference could be due to the amount of nitrate in the IR stream from the MBR, which is higher during mode 2 than during mode 1; hence, the amount of organic substrate available in the wastewater and required for nitrate removal is insufficient. It was determined that the ratio of influent biodegradable soluble $\mathrm{COD}(\mathrm{BSCOD})$ to nitrate nitrogen $\left(\mathrm{BSCOD} / \mathrm{NO}_{3}-\mathrm{N}\right)$ in mode 1 is $5.59 \pm 1.50 \mathrm{~g} \mathrm{BSCOD} / \mathrm{gNO}_{3}-\mathrm{N}$, which is higher than the value of $3.22 \pm 1.14 \mathrm{~g}$ BSCOD $/ \mathrm{g} \mathrm{NO}-\mathrm{N}$ in mode 2. Metcalf et al. (2004) estimated that the optimal ratio of BSCOD required to nitrate nitrogen reduced to nitrogen gas is $6.6 \mathrm{~g} \mathrm{BSCOD} / \mathrm{g} \mathrm{NO}_{3}-\mathrm{N}$, which is similar to the value obtained during mode 1 . Additionally, due to the higher IR ratio, the HRT in the RPS is shorter in mode 2 than in mode 1 (42 min vs. $60 \mathrm{~min}$ ). Therefore, it is assumed that there was not enough time for the denitrifying bacteria to implement complete reduction of nitrate as opposed to mode 1 .

Lowering the wastewater temperature can have a negative influence on the growth of microbial communities and their functional structures in biological wastewater treatment units (Chu and Wang, 2013; Sayi-Ucar et al., 2015). Jeyanayagam (2005) reported that the rates of nitrification and denitrification reduced to approximately $30 \%$ and $75 \%$, respectively, when the influent wastewater temperatures were lowered from $20^{\circ} \mathrm{C}$ to $10^{\circ} \mathrm{C}$. However, the results of this study did not indicate any notable influence of the temperature on denitrification, although the temperature of the influent wastewater varied between $13.1^{\circ} \mathrm{C}$ and $25.9^{\circ} \mathrm{C}$. This might be due to the formation 
and/or presence of various groups and species of microorganisms in the suspended biomass and biofilms (fixed biomass) of the attached growth on the surface of the rope media in the RPS and because each microorganism has its own optimum temperature level (Cydzik-Kwiatkowska, 2015; Mieczkowski et al., 2016). Therefore, an IR ratio of $100 \%$ is recommended for applications, corresponding to an HRT of wastewater in the RPS of approximately $1 \mathrm{~h}$.

It is interesting to note that the modularized RPS is not only capable of growing and maintaining abundant denitrifying bacteria for the nitrogen removal (denitrification) but is also designed to be highly versatile and compact for easy placement in restricted areas. Multiple modules of different sizes can be connected to increase the wastewater retention time and total specific surface area of the biofilm carrier. Hence, the incoming plug flow of the wastewater containing nutrients and organic matter is continuously delivered and streams over nitrifying bacterial biofilms that form on the surface of the media. In turn, waste contaminants will be absorbed, filtered, and degraded as the incoming flow trickles across the extensive growth surface of the biofilters, resulting in the increased rates of treatment and higher treatment efficiency of pollutants. The use of a separate anoxic tank or intermittent aeration regime within the same MBR tank would require more working volume, space for construction, operation and maintenance, and energy consumption to completely mix the contents and increase the contact with denitrifying bacteria.

Based on the above-mentioned results, a combined RPS and MBR process shows promise and is potentially feasible for wastewater treatment, enhancing the rate and removal efficiency of nitrogen in new systems and representing a retrofit to upgrade existing conventional wastewater treatment plants (Martin and Nerenberg, 2012). Furthermore, operational costs and energy requirements can potentially be effectively curtailed by reducing the IRs.

\subsection{Filtration performance and fouling behavior in the MBR}

Although the application of membrane technology in wastewater treatment has many practical benefits for the environment and society, its adoption is currently limited due to membrane fouling (Tan et al., 2015). This is an inevitable phenomenon in all applications involving membrane systems and a major challenge that has not yet been fully overcome (Judd, 2010; $\mathrm{Ng}$ et al., 2006). However, reducing the rate of membrane fouling and lengthening the chemical cleaning cycle, which remains under constant permeate flux, can be achieved with appropriate operating regimes.

Evolution profiles of the TMP, permeability, and MLSS in the MBR during real-time monitoring of the membrane performance at constant permeate flux are shown in Fig. 7. The results demonstrate that the TMP gradually increases over the study period, which is due to the adhesive particulate matter and growth of the biofilm on the surface and/or deep inside the membrane pores. The initial TMP value is $5 \mathrm{~cm} \mathrm{Hg}$. After operating for more than 4 months [including a one-month start-up operation and operating for more than 3 months in two modes at the fixed permeate flux of $\left.15.94 \mathrm{~L} /\left(\mathrm{m}^{2} \mathrm{~h}\right) ; \mathrm{LMH}\right]$ and without any chemical cleaning, the TMP only reaches $30.66 \mathrm{kPa}$ $(23 \mathrm{~cm} \mathrm{Hg})$ at the end of the study. The manufacturer recommends that the membrane system needs to undergo a chemical backwash process at a value of $40 \mathrm{~cm} \mathrm{Hg}\left(\mathrm{P}_{\max }\right)$ to restore the membrane permeability. Thus, based on the performance in the experiments, the TMP trend changes over the course of the operation (Fig. 7). Based on these results, the membrane system would require chemical cleaning after a MBR operating period of 5.6 months (168 days), which is nearly twice 
the time recommended by the manufacturer. However, average biomass concentrations of $4.83 \pm 1.24 \mathrm{~g} \mathrm{MLSS} / \mathrm{L}$ in the MBR and a specific aeration demand of $0.55 \pm 0.08 \mathrm{~m}^{3} /\left(\mathrm{h} \mathrm{m}^{2}\right)$ or $34.56 \pm 5.18 \mathrm{~m}^{3}$ air per $\mathrm{m}^{3}$ permeate flux should be maintained. Thus, this research shows that the combined RPS and MBR system can indeed enhance biological nitrogen and organic matter removal and mitigate the rate of membrane fouling. Therefore, the system provides a new choice of treatment or the renovation or retrofitting of existing membrane treatment systems to simultaneously improve the treatment quality and mitigate membrane fouling (Urbaniec et al., 2016).

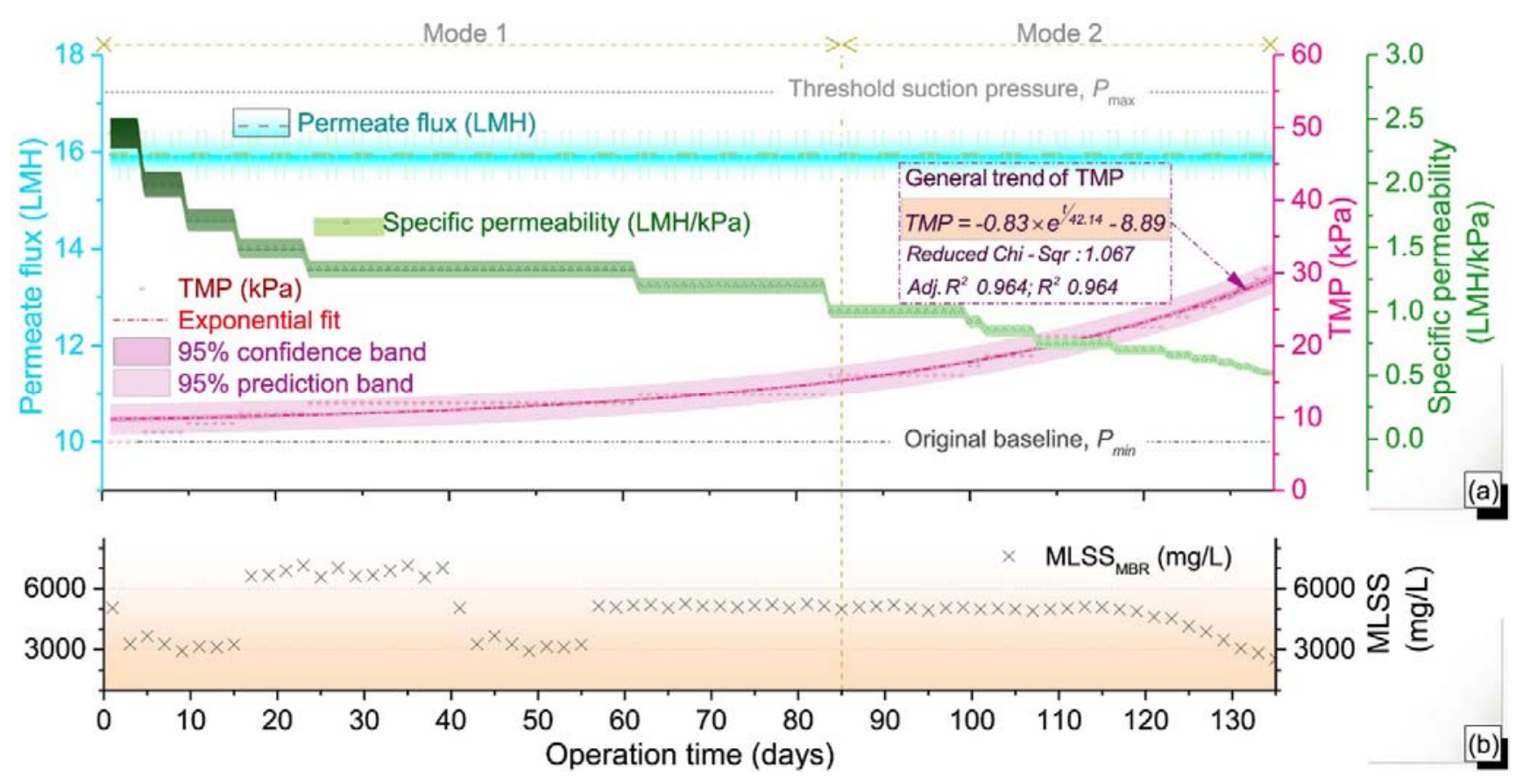

Fig. 7. Variations of the TMP, permeability, and MLSS concentrations in the MBR during membrane performance under constant permeate flux.

Furthermore, during the period of operation, the membrane permeability gradually declines from 2.39 to $0.52 \mathrm{LMH} / \mathrm{kPa}$. The results indicate that the membrane permeability is inversely proportional to the rate of membrane fouling at a given flux.

\section{Conclusions}

Although the characteristics of influent wastewater notably fluctuate and the temperature is relatively low, the hybrid pilot system exhibits an excellent ability and stability in removing organic carbon and nitrogen pollutants. Although the nitrification rate in the MBR is identical for both modes, the denitrification rate in the RPS is $116.95 \mathrm{mg} \mathrm{NO}-\mathrm{N} /(\mathrm{g}$ MLVSS $\cdot \mathrm{d})$ in mode 1 , which is 1.7-fold higher than the value obtained in mode 2 . Therefore, the nitrogen removal by the hybrid system is better during mode 1 than in mode $2(62.74 \%$ vs. $48.37 \%)$. However, the COD removal is slightly lower during mode 1 than in mode $2(92.82 \%$ vs. $95.08 \%)$. In addition, the membrane is robust and virtually completely removes solids; the chemical cleaning cycles could be considerably extended. 


\section{Acknowledgements}

This project was supported by grants from the Korean Ministry of Environment, as a "Global Top Project" (Project No. 2016002210003), and the National Research Foundation (NRF) of Korea (Grant No. NRF-2017R1D1A1B03035442). We would also like to thank Dankook Univeristy, Gentro Co., Ltd., and former Vice President Dr. S. D. Kim for this research material and advice, which allowed the completion of this work.

\section{Appendix A. Supplementary material}

Supplementary data associated with this article can be found, in the online version, at https://doi.org/10.1016/j.jclepro.2018.01.038.

\section{References}

Abbassi, B., Dullstein, S., R€abiger, N., 2000. Minimization of excess sludge production by increase of oxygen concentration in activated sludge flocs; experimental and theoretical approach. Water Res. 34, 139-146.

APHA, AWWA, WEF, 2003. Standard Methods for the Examination of Water and Wastewater. Washington DC, USA.

Choi, J.-H., Ng, H.Y., 2008. Effect of membrane type and material on performance of a submerged membrane bioreactor. Chemosphere 71, 853-859.

Chu, L.,Wang, J., 2013. Denitrification performance and biofilm characteristics using biodegradable polymers PCL as carriers and carbon source. Chemosphere 91, 1310-1316.

Cydzik-Kwiatkowska, A., 2015. Bacterial structure of aerobic granules is determined by aeration mode and nitrogen load in the reactor cycle. Bioresour. Technol. 181, 312-320.

de-Bashan, L.E., Bashan, Y., 2004. Recent advances in removing phosphorus from wastewater and its future use as fertilizer (1997e2003). Water Res. 38, 4222-4246.

Delrue, F., Stricker, A.E., Mietton-Peuchot, M., Racault, Y., 2011. Relationships between mixed liquor properties, operating conditions and fouling on two fullscale MBR plants. Desalination 272, 9-19.

Duan, L., Jiang, W., Song, Y., Xia, S., Hermanowicz, S.W., 2013. The characteristics of extracellular polymeric substances and soluble microbial products in moving bed biofilm reactor-membrane bioreactor. Bioresour. Technol. 148, 436-442.

Fulazzaky, M.A., Abdullah, N.H., Mohd Yusoff, A.R., Paul, E., 2015. Conditioning the alternating aerobiceanoxic process to enhance the removal of inorganic nitrogen pollution from a municipal wastewater in France. J. Clean. Prod. 100, 195-201.

Ge, S., Peng, Y., Wang, S., Guo, J., Ma, B., Zhang, L., Cao, X., 2010. Enhanced nutrient removal in a modified step feed process treating municipal wastewater with different inflow distribution ratios and nutrient ratios. Bioresour. Technol. 101, 9012-9019.

Geng, Z., Hall, E.R., 2007. A comparative study of fouling-related properties of sludge from conventional and membrane enhanced biological phosphorus removal processes. Water Res. 41, 4329-4338.

Geng, Z., Hall, E.R., B_erub_e, P.R., 2007. Membrane fouling mechanisms of a membrane enhanced biological phosphorus removal process. J. Membr. Sci. 296, 93-101.

Gonçalves, A.L., Pires, J.C.M., Sim oes, M., 2016. Wastewater polishing by consortia of Chlorella vulgaris and activated sludge native bacteria. J. Clean. Prod. 133, 348-357. 
Guo, J., Zhang, L., Chen, W., Ma, F., Liu, H., Tian, Y., 2013. The regulation and control strategies of a sequencing batch reactor for simultaneous nitrification and denitrification at different temperatures. Bioresour. Technol. 133, 59-67.

Halling-Sørensen, B., Jorgensen, S.E., 1993. The Removal of Nitrogen Compounds from Wastewater. Elsevier.

Hua, L.-C., Huang, C., Su, Y.-C., Nguyen, T.-N.-P., Chen, P.-C., 2015. Effects of electrocoagulation on fouling mitigation and sludge characteristics in a coagulation assisted membrane bioreactor. J. Membr. Sci. 495, 29-36.

Ilies, P., Mavinic, D.S., 2001. The effect of decreased ambient temperature on the biological nitrification and denitrification of a high ammonia landfill leachate. Water Res. 35, 2065-2072.

Jeyanayagam, S., 2005. True confessions of the biological nutrient removal process. Florida Water Resources J. 1, 37-46.

Judd, S., 2010. The MBR Book: Principles and Applications of Membrane Bioreactors for Water and Wastewater Treatment. Elsevier.

Kalyuzhnyi, S., Gladchenko, M., Mulder, A., Versprille, B., 2006. DEAMOX-new biological nitrogen removal process based on anaerobic ammonia oxidation coupled to sulphide-driven conversion of nitrate into nitrite. Water Res. 40, 3637-3645.

Kim, D.-J., Lee, D.-I., Keller, J., 2006. Effect of temperature and free ammonia on nitrification and nitrite accumulation in landfill leachate and analysis of its nitrifying bacterial community by FISH. Bioresour. Technol. 97, 459-468.

Le-Clech, P., Chen, V., Fane, T.A.G., 2006. Fouling in membrane bioreactors used in wastewater treatment. J. Membr. Sci. 284, 17-53.

Leiknes, T., Bolt, H., Engmann, M., Ødegaard, H., 2006. Assessment of membrane reactor design in the performance of a hybrid biofilm membrane bioreactor (BFMBR). Desalination 199, 328330.

Li, B., Qiu, Y., Zhang, C., Chen, L., Shi, H., 2016. Understanding biofilm diffusion profiles and microbial activities to optimize integrated fixed-film activated sludge process. Chem. Eng. J. 302, 269-277.

Martin, K.J., Nerenberg, R., 2012. The membrane biofilm reactor (MBfR) for water and wastewater treatment: principles, applications, and recent developments. Bioresour. Technol. 122, 83-94.

Metcalf, L., Eddy, H., Tchobanoglous, G., 2004. Wastewater Engineering: Treatment and Reuse. Metcalf \& Eddy, Inc., McGraw-Hill, New York, USA.

Mieczkowski, D., Cydzik-Kwiatkowska, A., Rusanowska, P., Swiatczak, P., 2016. Temperatureinduced changes in treatment efficiency and microbial structure of aerobic granules treating landfill leachate. World J. Microbiol. Biotechnol. 32, 91.

Ng, H.Y., Tan, T.W., Ong, S.L., 2006. Membrane fouling of submerged membrane Bioreactors: impact of mean cell residence time and the contributing factors. Environ. Sci. Technol. 40, 2706-2713.

Nguyen, D.D., Ngo, H.H., Guo,W., Nguyen, T.T., Chang, S.W., Jang, A., Yoon, Y.S., 2016. Can electrocoagulation process be an appropriate technology for phosphorus removal from municipal wastewater? Sci. Total Environ. 563e564, 549-556. 
Nguyen, D.D., Ngo, H.H., Kim, S.D., Yoon, Y.S., 2014a. A specific pilot-scale membrane hybrid treatment system for municipal wastewater treatment. Bioresour. Technol. 169, 52-61.

Nguyen, D.D., Ngo, H.H., Yoon, Y.S., 2014b. A new hybrid treatment system of bioreactors and electrocoagulation for superior removal of organic and nutrient pollutants from municipal wastewater. Bioresour. Technol. 153, 116-125.

Oram, B., 2011. Nitrates and nitrites in drinking water and surfacewaters. BF Environ. https://www.water-research.net/index.php/nitrate.

Plosz, B.G., Jobbagy, A., Grady Jr., C.P.L., 2003. Factors influencing deterioration of denitrification by oxygen entering an anoxic reactor through the surface. Water Res. 37, 853863.

Reboleiro-Rivas, P., Martín-Pascual, J., Ju_arez-Jimenez, B., Poyatos, J.M., Vílchez-Vargas, R., Vlaeminck, S.E., Rodelas, B., Gonz_alez-L_opez, J., 2015. Nitrogen removal in a moving bed membrane bioreactor for municipal sewage treatment: community differentiation in attached biofilm and suspended biomass. Chem. Eng. J. 277, 209-218.

Riffat, R., 2012. Fundamentals ofWastewater Treatment and Engineering. CRC Press. Rosenberger, S., Evenblij, H., te Poele, S., Wintgens, T., Laabs, C., 2005. The importance of liquid phase analyses to understand fouling in membrane assisted activated sludge processesdsix case studies of different European research groups. J. Membr. Sci. 263, 113-126.

Sayi-Ucar, N., Sarioglu, M., Insel, G., Cokgor, E., Orhon, D., van Loosdrecht, M., 2015. Longterm study on the impact of temperature on enhanced biological phosphorus and nitrogen removal in membrane bioreactor. Water Res. 84, 8-17.

Sriwiriyarat, T., Ungkurarate,W., Fongsatitkul, P., Chinwetkitvanich, S., 2008. Effects of dissolved oxygen on biological nitrogen removal in integrated fixed film activated sludge (IFAS) wastewater treatment process. Journal of Environmental Science and Health Part A 43, 518527.

Syron, E., Casey, E., 2008. Membrane-aerated biofilms for high rate biotreatment: performance appraisal, engineering principles, scale-up, and development requirements. Environ. Sci. Technol. 42, 1833-1844.

Tan, J.-M., Qiu, G., Ting, Y.-P., 2015. Osmotic membrane bioreactor for municipal wastewater treatment and the effects of silver nanoparticles on system performance. J. Clean. Prod. 88, 146-151.

Tan, T.W., Ng, H.Y., 2008. Influence of mixed liquor recycle ratio and dissolved oxygen on performance of pre-denitrification submerged membrane bioreactors. Water Res. 42, 11221132.

Urbaniec, K., Mikul_ci_c, H., Dui_c, N., Lozano, R., 2016. SDEWES 2014 - sustainable development of energy, water and environment systems. J. Clean. Prod. 130, 1-11.

Urbaniec, K., Mikul_ci_c, H., Rosen, M.A., Dui_c, N., 2017. A holistic approach to sustainable development of energy, water and environment systems. J. Clean. Prod. 155, 1-11.

van Rijn, J., Tal, Y., Schreier, H.J., 2006. Denitrification in recirculating systems: theory and applications. Aquacult. Eng. 34, 364-376.

Yang, P., Zhang, Z., 1995. Nitrification and denitrification in the wastewater treatment system. In: Proceedings of the UNESCOduniversity of Tsukuba International Seminar on Traditional 
Technology for Environmental Conservation and Sustainable Development in the AsianPacific Region, Tsukuba Science City, Japan, pp. 11-14.

Yang, S., Yang, F., Fu, Z., Wang, T., Lei, R., 2010. Simultaneous nitrogen and phosphorus removal by a novel sequencing batch moving bed membrane bioreactor for wastewater treatment. J. Hazard Mater. 175, 551-557.

Ye, Y., Ngo, H.H., Guo, W., Liu, Y., Zhang, X., Guo, J., Ni, B.-j., Chang, S.W., Nguyen, D.D., 2016. Insight into biological phosphate recovery from sewage. Bioresour. Technol. 218, 874881.

Yoon, T.I., Lee, H.S., Kim, C.G., 2004. Comparison of pilot scale performances between membrane bioreactor and hybrid conventional wastewater treatment systems. J. Membr. Sci. $242,5-12$.

Zheng, X., Pan, J., Zhang, F., Liu, E., Shi, W., Yan, Y., 2016. Fabrication of free-standing biotemplate mesoporous hybrid film for high and selective phosphate removal. Chem. Eng. J. 284, 879-887. 